\title{
Liberdade de expressão versus direito à comunicação: a regulação da comunicação audiovisual na Argentina
}

Freedom of Speech versus Right to Communicate: The Audiovisual

Communication Regulation in Argentina

Submetido(submitted): 15 de janeiro de 2012

Parecer(revised): 18 de março de 2012

Aceito(accepted): 7 de abril de 2012

Glauciene Lara*

\section{Resumo}

Este trabalho propõe-se a determinar a relação conceitual entre os termos "liberdade de expressão", "liberdade de imprensa" e "direito à comunicação", frente ao contexto histórico internacional da NOMIC e de ponderações doutrinárias, mediante referência à alteração do arcabouço normativo de comunicação argentino implementada em 2009. Parte-se da revisão bibliográfica, posteriormente aplicada ao caso argentino, para identificar a origem desses termos e mudanças conceituais sofridas desde as revoluções liberais até hoje. Conclui-se pela ausência de oposição entre liberdade de expressão e direito à comunicação ou liberdade de expressão e regulação, como mostra o caso argentino, que passa por uma redefinição do que se entende por liberdade de expressão desde a adoção da Lei 26.522.

Palavras-chave: regulação, radiodifusão, liberdade de expressão, direito à comunicação, Argentina.

\section{Abstract}

This paper determine the relationship between "freedom of speech", "freedom of press" and "right to communicate" in the international context of NWICO by way of analyzing the legal reform of 2009 on the Argentinean communications law. The study goes deep in the review of the literature applied to the Argentinean case, in order to specify the origin of the aforementioned terms and conceptual changes experienced since the liberal revolutions to date. It concludes that there is no opposition between freedom of speech and right to communicate or between freedom of speech and regulation, as one can see in the Argentinean case, which adopted a redefinition of the meaning of freedom of speech since the approval of the new broadcasting act.

Keywords: regulation, broadcasting, freedom of speech, right to communicate, Argentina.

\footnotetext{
*Mestranda em Políticas de Comunicação do Programa de Pós-Graduação em Comunicação Social da Universidade de Brasília. Contato: glauciene_lara@yahoo.com.br.
} 


\section{Introdução}

Segundo os consultores da Unesco Toby Mendel e Eve Salomon (2011), a regulação desse setor objetiva garantir a liberdade de expressão, ou o direito à comunicação. Trata-se de um mecanismo que fortalece a democracia, na medida em que garante a pluralidade e o respeito aos direitos fundamentais. Entretanto, de acordo com Mendel e Salomon (2011), a regulação só é democrática quando baseada nos princípios de transparência e independência do governo - o que não significa livre de intervenção estatal - e do mercado.

A regulação da comunicação audiovisual existe nos Estados Unidos desde 1926, quando foi criada a Federal Radio Comission (FRC), que em 1934 se transformou em Federal Communication Comission (FCC), o órgão regulador das comunicações norte-americanas. Na Europa, há exemplos de órgãos reguladoras com a função de garantir a pluralidade e a diversidade dos meios de comunicação, os direitos dos cidadãos de receber informações e também de informar e os direitos de minorias, como a proteção de crianças e adolescentes, a igualdade de gênero, a igualdade racial, a acessibilidade (LINS, 2002).

Hoje, a Europa e os Estados Unidos também estão envolvidos em outro debate, para o qual a América Latina começa a dar atenção: o da regulação da internet e de conteúdos audiovisuais na internet. Trata-se de um campo novo e fértil a ser estudado. Nos países latino-americanos, a posição dos meios de comunicação quanto à regulação do setor sempre foi de resistência e até de omissão em discutir a questão e pautar a sociedade. Paulino Motter (1994) fala em batalha invisível e Murilo Ramos (1993), em agenda proibida, para se referir aos debates sobre a regulação da radiodifusão. $\mathrm{O}$ assunto pouco aparece na mídia, como mostraram os embates sobre o capítulo da Comunicação Social na Constituinte brasileira (MOTTER, 1994). Quando o tema surge, o discurso repetido pelos empresários associa a regulação e os órgãos reguladores à censura, verdadeira ameaça à liberdade de expressão. ${ }^{1}$ Para clarear essa confusão teórica, buscaremos as raízes

${ }^{1}$ Este excerto jornalístico é esclarecedor: "As teses são polêmicas. Entre os sindicatos, ONGs e o PT, por exemplo, prevalece a ideia de pôr os meios de comunicação sob controle público e social, velha tese dos partidos de esquerda que vez por outra volta à agenda...O PT, por exemplo, aprovou resolução segundo a qual Revista de Direito, Estado e Telecomunicações, v. 4, n. 1, p. 137-172 (2012) 
históricas desses conceitos e seu desenvolvimento no cenário político internacional e nos grandes sistemas do direito contemporâneo.

\section{Raízes históricas}

A origem da liberdade de imprensa costuma ser localizada na Inglaterra de 1644, quando John Milton publica o Areopagitica (Pela liberdade de imprimir sem autorização nem censura). O imprimatur era responsável por conceder a autorização prévia para a impressão de livros, folhetos e periódicos, uma prerrogativa outorgada pelo monarca às editoras autorizadas. Milton defendia a liberdade de impressão sem censura nem autorização prévia e, como consequência, a liberdade de expressão dos pensamentos, opiniões e ideias:

os meios de comunicação têm de se submeter ao controle público e social. Mas há divisão no partido. O deputado Cláudio Vingnati (PT-SC), que comandou a Frente Parlamentar da Mídia Regional, acha que o PT cometeu grande erro ao falar no controle público e social. "A resolução do PT teria de ter deixado claro que a $1^{\text {a }}$ Confecom não poderá permitir enredar-se por nenhuma tendência de controle autoritário de meios e conteúdos por quem quer que seja, muito menos permitir recrudescer controles autoritários pelo Estado', disse ele." (O ESTADO DE SÃO PAULO. Foco é o Controle Social da Mídia, 15 dez. 2009); "O próximo ataque organizado à liberdade de expressão se dará em março, com a Segunda Conferência Nacional de Cultura. (...) O evento é a continuação por outros meios da batalha pela implantação da censura à imprensa no Brasil. Isso começou em agosto de 2004, com a iniciativa, abortada, de criar um Conselho Federal de Jornalismo. Nos últimos seis meses foram feitas mais duas tentativas. Uma delas na Conferência Nacional de Comunicação. A outra com o PNDH-3, o Programa Nacional de Direitos Humanos. (...) Todos embutem a criação de um tribunal para censurar, julgar e punir jornalistas e órgãos de comunicação que desobedeçam às normas governamentais. É um figurino de atraso." (VEJA. A obsessão totalitária. v.43, n.4, p.64-65, 27 jan. 2010); "Uma das 633 deliberações da Conferência Nacional de Comunicação foi a criação de conselhos de comunicação estatuais e municipais, com o objetivo de controlar a imprensa. Os petistas se esforçam por disseminá-los. (...) Por trás dessas iniciativas está o ministro da Supressão da Verdade, Franklin Martins, o capitão do mato da caça aos veículos que não se subordinam aos interesses petistas. Ele próprio tenta converter as deliberações da Confecom em lei federal." (VEJA. A obsessão totalitária. v. 43, n. 4, p. 64-65, 27 de janeiro de 2010). 
O que vós gostaríeis, pois, de fazer? Por acaso, suprimir o florescer do conhecimento e a nova luz emanada e, dia após dia, ainda emanando nesta cidade? Ou instaurar uma oligarquia de vinte monopolizadores, para que nossas mentes voltem a padecer de fome, quando só conheçam o que nos for por eles mediado? (...) Deem-me a liberdade de saber, de falar e de arguir livremente segundo minha consciência, acima de todas as libertades ${ }^{2}$ [tradução nossa]. (MILTON, 1976, p. 88-89)

Em 1788, Mirabeau lança uma versão francesa do texto de Milton, chamada Sur la liberté de la presse. Daí surge o termo liberdade de imprensa, considerada pelos iluministas um dos pilares do Estado moderno. "Na concepção do Iluminismo, ao assegurar a publicidade, o controle dos atos do poder público e o triunfo da verdade e da razão, a liberdade de imprensa favorecia a aplicação de todas as demais liberdades." (MAIA; PEREIRA, 2011, p. 83). Para os iluministas, os possíveis inconvenientes causados pela imprensa como a revolta, os tumultos populares, a calúnia e a difamação, seriam irrisórios ao lado das vantagens que ela traz. Os franceses defensores dessa liberdade também a associavam ao crescimento econômico da Inglaterra.

Assim, a liberdade de imprensa e a liberdade de expressão são heranças do Iluminismo e das revoluções liberais. A Declaração dos Direitos do Homem e do Cidadão, elaborada pela Assembleia Nacional francesa em 1789, elenca, em 17 artigos, os direitos naturais, inalienáveis e sagrados do homem moderno. Pelo menos dois artigos se referem diretamente à liberdade de expressão:

Art. 10. Ninguém deve ser perseguido por suas opiniões, mesmo religiosas, desde que sua manifestação não atrapalhe a ordem pública estabelecida pela lei.

Art. 11. A livre comunicação dos pensamentos e opiniões é um dos direitos mais preciosos do homem: todo cidadão pode, portanto, falar, escrever, imprimir livremente, embora deva

\footnotetext{
2"Qué gustaríais, pues, de hacer? Suprimir acaso toda esa florida cosecha de conocimiento y nueva luz manada y aún día tras día manando en esta ciudad? O instaurar una oligarquía de veinte acaparadores sobre ello, para que vuelv an nuestras mentes a padecer hambre, cuando sólo conozcan lo para nosotros medido en su celemín? (...) Dadme la libertad de saber, de hablar y de arguir libremente según mi conciencia, por cima de todas las libertades."
} 
responder pelo abuso dessa liberdade nos casos determinados pela lei. (DECLARAÇÃO DOS DIREITOS DO HOMEM E DO CIDADÃO, 1789)

Como se trata de uma luta contra o Estado absolutista, mais do que natural que o liberalismo conceba essas liberdades como negativas, ou seja, sem interferência externa. Assim mesmo, o artigo seguinte da Declaração dos Direitos do Homem e do Cidadão estabelece que esses direitos, entre eles a liberdade de expressão e de imprensa, devem ser garantidos por uma força pública:

Art. 12. A garantia dos direitos do homem e do cidadão necessita de uma força pública: essa força é, portanto, instituída para o benefício de todos e não para a utilidade particular daqueles a quem ela está confiada. (DECLARAÇÃO DOS DIREITOS DO HOMEM E DO CIDADÃO, 1789)

Essa força pública é o Estado e isso fica ainda mais claro no artigo seguinte, que institui o tributo para a manutenção da força pública. $\mathrm{O}$ art. 12 também revela a concepção garantista do direito romano-germânico (DAVID, 2002), também chamado de europeu continental, no qual se insere o francês: o Estado é a instituição garantidora dos direitos do cidadão, que assegura seu cumprimento.

A Declaração dos Direitos do Homem e do Cidadão inspirou o Direito Constitucional do mundo moderno, não só os derivados da família romanogermânica, mas até os da Common Law. Inspirou, por exemplo, a primeira emenda à Constituição dos Estados Unidos, promulgada em 1791. O texto diz que o Congresso não editará nenhuma lei que restrinja a liberdade de expressão ou da imprensa. ${ }^{3}$ Como veremos adiante, essa emenda até hoje é objeto de debates sobre a intervenção ou não do Estado na garantia da liberdade de expressão.

No auge da expansão das ideias liberais, Benjamin Constant, cuja obra é considerada o início da reflexão liberal sobre jornalismo, escreve um

${ }^{3}$ Primeira emenda à Constituição dos Estados Unidos: "Congress shall make no law respecting an establishment of religion, or prohibiting the free exercise thereof; or abridging the freedom of speech, or of the press; or the right of the people peaceably to assemble, and to petition the Government for a redress of grievances." 
discurso no século XIX sobre as liberdades individuais, chamadas por ele de modernas. Sobre a intervenção do Estado, Constant afirma:

esta intervenção é sempre incômoda. Todas as vezes que o poder coletivo quer intrometer-se nas especulações particulares, ele atrapalha os especuladores. Todas as vezes que os governos pretendem realizar negócios, eles o fazem menos bem e com menos vantagens do que nós. (CONSTANT; 1985, p.14)

O autor condena a intervenção estatal nas liberdades individuais, entre elas, a liberdade de expressão. Uma posição que deve ser compreendida dentro do contexto da luta das revoluções liberais contra o Estado absolutista e censor. Segundo Constant, nenhuma das instituições das repúblicas antigas que impediam a liberdade individual é aceitável nos tempos modernos e cita como exemplo a censura:

$\mathrm{Na}$ França, uma instituição tão arbitrária como a censura seria ao mesmo tempo ineficaz e intolerável. No estágio atual da sociedade, os costumes compõem-se de matizes tênues, vagos, imperceptíveis, que se desnaturariam de mil maneiras se tentássemos dar-lhes mais precisão. Somente a opinião pode atingi-los; só ela pode julgá-los porque são da mesma essência. Ela se sublevaria contra toda autoridade positiva que quisesse lhe dar mais rigor. Se o governo de um povo pretendesse, como os censores de Roma, desonrar um cidadão pro uma decisão discriminatória, a nação inteira reclamaria contra essa sentença, não ratificando as determinações da autoridade. (CONSTANT; 1985, p.20)

Além de condenar a censura, Constant defende que a opinião ou liberdade de expressão seja protegida da intervenção do Estado e de instituições antigas. $\mathrm{O}$ autor também apresenta uma das finalidades da liberdade de expressão: ela é a forma com que a sociedade moderna controla as ações do Estado. Assim, deve ser um direito inalienável e universal.

\section{A Nova Ordem Mundial da Informação e da Comunicação}

Após a Segunda Guerra Mundial, a Organização das Nações Unidas (ONU) publica, em 1948, a Declaração Universal dos Direitos Humanos, 
cujo art. $19^{4}$ assegura a liberdade de expressão como direito do ser humano a ter opiniões e de receber e transmitir informações. Tanto a ONU quanto a Organização das Nações Unidas para a Educação, a Ciência e a Cultura (Unesco) contribuíram para o debate no campo da comunicação e da informação no pós-guerra.

O mundo pós-Segunda Guerra polarizou-se em duas dimensões: capitalismo versus comunismo e desenvolvidos versus subdesenvolvidos. De acordo com Carlsson (2003), a ideia de desenvolvimento nacional nasceu no fim da Segunda Guerra Mundial e entrou na agenda internacional nos anos 1950, introduzida pelos Estados Unidos, uma das potências mundiais interessadas em exportar seu modelo de sociedade. O Primeiro e o Segundo Mundo competiam em pontos de vista sobre como a vida social deveria estar organizada para atingir a "boa sociedade", o bem comum. Essas ideias eram exportadas para o Terceiro $\mathrm{Mundo}^{5}$, que emergiu com a independência das colônias e a formação de países em desenvolvimento. Esses países do Terceiro Mundo, com a ajuda do Primeiro e do Segundo, deveriam se desenvolver em sociedades modernas. Isso não significa que o Primeiro e o Segundo Mundos eram iguais, equilibrados. A industrialização, a pujança dos Estados ocidentais, o desenvolvimento dos mercados mundiais e a emergência de blocos militares deram ao Ocidente poder econômico, político e militar, que pode ser chamado de hegemônico.

O papel das comunicações assumiu proeminência nesse processo, não apenas no quesito avanços tecnológicos. Havia dois modelos de desenvolvimento. O paradigma da modernização engloba as teorias relativas à modernização, desenvolvimento político e econômico e transferência de tecnologia. De acordo com esse paradigma, de ênfase essencialmente otimista, os problemas dos países desenvolvidos são resultantes de características inerentes à história dos territórios. A comunicação pode

\footnotetext{
${ }^{4}$ Toda pessoa tem direito à liberdade de opinião e expressão; este direito inclui a liberdade de, sem interferência, ter opiniões e de procurar, receber e transmitir informações e ideias por quaisquer meios e independentemente de fronteiras. (DECLẢRAÇÃO UNIVERSAL DOS DIREITOS HUMANOS, 1948)

${ }^{5} \mathrm{O}$ termo Terceiro Mundo foi criado em 1955, na Conferência de Bandung, em que participaram cerca de 30 países da África e da Ásia. A expressão foi criada para que esses países se identificassem como uma terceira força entre o capitalismo e o comunismo.
} 
facilitar o progresso em direção a uma sociedade moderna, oposta à tradicional. Baseia-se na liberdade individual e no conceito de livre fluxo de informação: nenhuma nação deve barrar o fluxo de informação entre os países. Ele significa uma ideologia de ausência de Estado e de regulação dos fluxos internacionais diga-se, de passagem, dirigida ao resto do mundo, porque os EUA têm uma agência que regula as comunicações desde 1934, a Federal Communication Comission (FCC). Essa ideia espalhou-se rapidamente pelo mundo após a Segunda Guerra. Um dos motivos para o sucesso dessa expansão, de acordo com Carlsson (2003), seria o fato dos países estarem cansados da propaganda de guerra e da censura que o conflito impunha. Este modelo acaba sendo um fluxo único, vertical de comunicação: da elite para o povo; do Primeiro Mundo para os demais.

Já o paradigma da dependência reúne as teorias relativas ao imperialismo, subdesenvolvimento, revolução e libertação. Vê o subdesenvolvimento como resultado do capitalismo e de suas expressões, tais como o colonialismo e o imperialismo - o subdesenvolvimento na periferia é um pré-requisito para o desenvolvimento no centro. Enxerga a comunicação mais como uma questão de imperialismo midiático: os meios de comunicação de massa reforçam o domínio da metrópole sobre seus satélites. Dito paradigma também é essencialmente pessimista sobre o desenvolvimento em países do terceiro mundo e defende o equilíbrio social e, consequentemente, o equilíbrio dos fluxos de informação.

O paradigma da modernização era dominante nos anos 1950 e 60 e a visão que o caracteriza coincide largamente com a ideia de assistência para o desenvolvimento, que era adotada pelas Nações Unidas e pela Unesco no período. A Unesco era vista como um sistema de transferência de recursos dos países ricos para os pobres. A assistência da Unesco tinha foco principalmente na transferência de tecnologia para que cada país tivesse pelo menos 10 jornais diários, 5 receptores de rádio e dois aparelhos de TV a cada mil habitantes. Outro papel de destaque da Unesco era o de figurar como uma das maiores editoras do mundo. Muitos relatórios de comunicação de massa foram lançados entre os anos 1970 e 80. Esse papel contribuiu para a Unesco se tornar a principal arena de debate sobre os sistemas de comunicação entre nações e regiões do mundo. A partir dos anos 1970, a Unesco também passou a atuar na promoção de acordos entre 
as nações-membro. Antes, alguns acordos relativos à comunicação e à informação foram assinados na Assembleia-Geral da ONU.

$\mathrm{O}$ rápido desenvolvimento tecnológico nas comunicações levou à necessidade de uma regulação internacional, por exemplo, do uso do espaço para os satélites de comunicação. Começaram as tensões entre os países industrializados, uma guerra de ideias na arena internacional, constantemente alimentada pela Guerra Fria. Entre o pós-guerra e 1980, 41 documentos foram assinados -27 resoluções, oito tratados e convenções e seis declarações. Eles focam em elementos variados da comunicação de massa e especificam objetos para a regulação em sete tópicos: direitos e liberdades de acesso à informação, regulação do uso de satélites de comunicação, desenvolvimento dos países do terceiro mundo, propaganda de paz e segurança, discriminação e nova ordem mundial da informação e comunicação (CARLSSON, 2003). Mas, segundo Carlsson (2003), o conteúdo desses documentos é formulado no nível das abstrações, o que reflete a dificuldade dos países, num mundo de extrema polarização ideológica, em chegar a um acordo sobre medidas concretas. Eles podem ser vistos como uma tentativa de estabelecer uma certa ordem sobre os fluxos da informação no sistema político internacional. A autora classifica esses documentos em três grupos:

1) 1945 - 59: predominância da liberdade de informação e dos fluxos livres de informação. A assistência para o desenvolvimento de países do terceiro mundo recebeu grande atenção nesse período.

2) 1960 - 69: grande desenvolvimento tecnológico na área de comunicação. Criou-se uma necessidade de regular a tecnologia no plano internacional. Os documentos foram formulados da perspectiva dos países desenvolvidos.

3) 1970 - 79: o debate da Unesco passou a ser sobre mídia e imperialismo cultural e suas consequências. Os países que ficaram independentes queriam proteger sua soberania, representada por uma nova perspectiva na questão dos livres fluxos de informação. Os países do Ocidente frequentemente eram minoria, já que as nações independentes com frequência votavam junto com o bloco do Leste União Soviética. Nessa época, os países do Terceiro Mundo foram capazes de influenciar o conteúdo de documentos e tratados e o número de acordos alcançados. A descolonização superou o debate da assistência 
para o desenvolvimento no sentido político-jurídico, econômico e cultural. Os conflitos eram muitos, principalmente no sentido de se adotar uma declaração sobre a comunicação de massa, a qual depois de muito embate foi aprovada em 1978. O embate se polarizava entre 0 compromisso dos Estados Unidos com os fluxos livres de informação e a visão da União Soviética de controle estatal. Os países do Terceiro Mundo criticavam a visão do livre fluxo de informação como sendo apenas uma via de informação e expressão das ambições imperialistas. Além do conflito Oeste-Leste, surge também o Norte-Sul. A formação da OPEP e os choques do petróleo contribuíram para que o Terceiro Mundo tivesse mais voz.

Em 1974, a ONU adotou uma declaração para o estabelecimento da nova ordem internacional da economia. Ela consistiu em um desafio ideológico frontal para o liberalismo. Na prática, isso significava que os países demandavam acordos mais justos, assistência econômica e acesso à tecnologia ocidental. As vozes que clamavam por uma nova ordem econômica mundial também se estenderam para o campo da comunicação. Nos fóruns internacionais como a ONU e a Unesco, os países do Terceiro Mundo formaram uma aliança para demandar uma nova ordem mundial da informação e da comunicação - NWICO, em inglês, ou NOMIC, em português. A NOMIC é baseada em ideias sobre o papel que a comunicação tem no desenvolvimento dos países, por um lado, e por outro lado, nas relações entre países desenvolvidos e em desenvolvimento. O Terceiro Mundo constatou que como a informação no mundo mostra um desequilíbrio que favorece alguns e ignora outros, é um dever dos países em desenvolvimento mudar essa situação e obter a descolonização da informação para iniciar uma nova ordem mundial da informação e da comunicação. Os sistemas de informação estariam desenhados para atender aos países desenvolvidos. Os sistemas de mídia dos países pobres eram fracos e não podiam suprir seus países de notícias. Eles eram extremamente dependentes de agências de notícias internacionais. A NOMIC, portanto, demandava regulação da mídia e dos setores da comunicação em nível internacional.

Nesse mesmo ano, a Suécia introduziu o conceito de direito à comunicação na Conferência Geral da ONU. O termo right to communicate foi criado em 1969 pelo francês Jean d'Arcy, diretor de Meios Audiovisuais 
da ONU de 1961 a 1971. É um desdobramento do que se entende por liberdade de expressão, que inclui também o direito de participar da comunicação pública nos níveis internacional, nacional, local e individual. $\mathrm{O}$ conceito de direito à comunicação se identificou com o debate do Terceiro Mundo por uma Nova Ordem Mundial da Informação e da Comunicação, associado ao paradigma da dependência apoiado pela União Soviética. Nesse contexto, a liberdade de expressão esteve mais ligada à ideia de livre fluxo de informação e ao paradigma da modernização, defendido pelos governos liberais dos países do Ocidente, em especial os Estados Unidos e a Inglaterra.

Para alcançar a nova ordem mundial da informação e da comunicação, de acordo com os documentos da época, os países em desenvolvimento demandavam quatro "Ds":

1) Democratização: medidas para um maior equilíbrio dos fluxos de informação são necessárias. A base desse parâmetro é que o povo e os indivíduos têm o direito de adquirir um retrato plural e democrático da realidade assim como se expressar livremente através dos meios de comunicação e cultura.

2) Descolonização: baseia-se na auto-determinação, na independência nacional, na identidade cultural. 0 direito de toda nação de proteger sua soberania nacional e sua identidade cultural. Alguns conceitos vêm do paradigma da dependência.

3) Desmonopolização: 0 monopólio de corporações transnacionais é uma ameaça para a independência dos países do terceiro mundo. 0 foco são as operações das corporações transnacionais. Toda nação tem o direito de desenvolver seu próprio sistema de informação independente, em particular pela regulação das atividades das corporações transnacionais. Essa ênfase também reflete a influência do paradigma da dependência.

4) Desenvolvimento: os meios de comunicação de massa têm um papel vital no processo de desenvolvimento. Os países do terceiro mundo se juntam para demandar uma distribuição mais justa de recursos para a comunicação no mundo. Elementos-chave: necessidade de políticas públicas nacionais de comunicação, de desenvolvimento da infraestrutura, do estabelecimento de serviços nacionais de notícias e de novos intercâmbios regionais de notícias, colaboração técnica entre 
regiões, do uso de cooperação horizontal, ajuda e solidariedade entre os países em desenvolvimento. Aqui, revela-se uma utopia: o Terceiro Mundo queria ajuda dos próprios países desenvolvidos para se livrar da dependência deles.

Havia um movimento claro, no Terceiro Mundo, de rejeição do paradigma da modernização, em favor da auto-determinação, independência nacional, identidade cultural e de um fluxo democrático de informação entre as nações.

\subsection{Comissão McBride}

A demanda pela nova ordem mundial da informação na Unesco provocou tensões na organização da Conferência Geral em 1976, em Nairóbi. A formulação de uma declaração sobre os meios de comunicação de massa eram o ponto número um da agenda. Entretanto, nenhuma declaração foi aprovada na conferência. Em vez disso, instituiu-se a Comissão Internacional para o Estudo dos Problemas da Comunicação, mais conhecida como Comissão Mcbride. O objetivo principal da Comissão era analisar os problemas da comunicação, nos seus diferentes aspectos, com a perspectiva de estabelecer uma nova ordem internacional da economia e de medidas para serem tomadas no sentido de instituir uma nova ordem mundial da informação.

Os países em desenvolvimento não ficaram insatisfeitos com o resultado da conferência, porque uma comissão como essa significava reconhecer o desafio de mudar o status quo no sistema de política internacional.

A escolha dos membros da Comissão obedeceu critérios de pluralismo: experiência e qualificação dos integrantes, corrente intelectual, tradição cultural e a maior diversidade de sistemas econômicos e sociais das principais regiões do mundo. Foram 15 membros, além do presidente irlandês Sean McBride, político, diplomata e Prêmio Nobel da Paz, que deu nome à comissão. Nenhum dos integrantes era brasileiro. Da América Latina, um chileno e o colombiano Gabriel García Marquez. A China foi o único país convidado que desistiu de nomear um membro. Os integrantes foram escolhidos com base em méritos pessoais e deveriam representar somente eles mesmos, embora seis deles fossem políticos em nível nacional e outros cinco fossem ativos na política. Três integrantes eram acadêmicos. 


\subsection{Relatório McBride}

A Comissão baseou-se em 94 estudos internacionais para, em dois anos, escrever o relatório, publicado em 1980. Na introdução, Sean McBride tenta defirir a NOMIC: "mais justiça, mais equilíbrio, mais reciprocidade na troca de informações, menos dependência nos fluxos de comunicação, na difusão das mensagens, mais auto-suficiência e identidade cultural, mais benefícios para toda a humanidade" (UNESCO, 1983, p.20).

Também na introdução, McBride relata que os embates entre visões de mundo estiveram presentes na comissão formada por 16 membros com concepções políticas distintas. Em alguns pontos, o relatório mostra essas contradições. Mas a comissão conseguiu chegar a um acordo em diversos temas, "quando o consenso parecia irreconciliável". Por causa dessas diferenças, o relatório não traz muitas medidas concretas para as políticas de comunicação, mas diretrizes.

O texto é dividido em cinco partes. A quinta parte oferece 82 recomendações para os problemas estudados. O trabalho da comissão não se resumiu aos países em desenvolvimento; tratou de toda a humanidade, porque, segundo o relatório, a menos que a mudança fosse feita em todas as partes do mundo, não seria possível atingir a liberdade, reciprocidade e independência nas trocas de informação.

A comissão confirmou o desequilíbrio dos fluxos de informação entre os países e destacou desigualdades na distribuição dos recursos da comunicação. Ela também afirmou que isso traria consequências para os países em desenvolvimento e para o nível internacional. Criticou a comercialização da informação e a expansão do mercado de publicidade e destacou, ainda, a importância da função social da informação.

Ulla Carlsson (2003) divide as recomendações em quatro eixos:

1) O desenvolvimento dos países do Terceiro Mundo, para que eles se tornem realmente independentes e auto-suficientes e desenvolvam suas identidades culturais. As propostas incluem políticas nacionais de comunicação, construção de infraestrutura, distribuição equilibrada dos recursos da comunicação global, limitar as atividades das corporações transnacionais e dar tratamento preferencial à mídia não-comercial.

2) Melhores condições para os jornalistas e para a prática jornalística: regras éticas para a prática do jornalismo, melhorar a capacitação, fontes múltiplas de informação. 
3) Democratização da comunicação, ou seja, acesso e participação rumo ao direito à comunicação. Isso inclui garantia dos direitos humanos; abolição da censura; independência editorial; limites para a concentração e o monopólio de mídia; limites para a influência dos anunciantes no conteúdo e nas políticas de mídia; atenção às necessidades das mulheres, crianças e minorias; e promoção da comunicação horizontal.

4) Cooperação internacional: assistência para o desenvolvimento, apoio aos fóruns regionais e aos projetos colaborativos.

Após 1980, a Unesco ainda conseguiu aprovar o acordo sobre o direito à comunicação em 1983. Em 1985, os EUA saíram da Unesco acompanhados pela Grã-Bretanha um ano depois. O orçamento da Unesco caiu vertiginosamente, o que inviabilizou sua atuação. $\mathrm{O}$ boicote à Unesco, a ascensão do neoliberalismo, a queda do Muro de Berlim, que simbolizou o fim do socialismo soviético, e o avanço da globalização deixaram as diretrizes do relatório McBride só no papel. A promessa da globalização carrega muito do paradigma da modernização e dos fluxos livres de informação.

Segundo Carlsson (2003), o mundo hoje está fragmentado para o debate internacional da comunicação ganhar aceitação. Não há mais base política para a regulação internacional da mídia, como houve em 1970. Entretanto, apesar de os fluxos contemporâneos de notícias terem maior volume e maior diversificação de conteúdos do que os dos anos 1970, a origem deles pouco mudou: Europa e Estados Unidos. Nos países em desenvolvimento, há também grandes conglomerados locais e regionais, por exemplo, a Televisa, mexicana, e a Globo, brasileira. As relações de marginalização entre os países desenvolvidos e em desenvolvimento parecem prevalecer e o potencial de mudança no fluxo da informação que a internet prometia não se confirmou.

Durante toda a década de 1990, a Unesco teve atuação tímida e só nos anos 2000 retoma com mais força suas atividades, sob outra orientação, caracterizada pelo pluralismo: problemas globais, soluções locais. Esse enfoque, segundo Carlsson (2003), resulta na era da governança multilateral, do jogo entre múltiplos atores em múltiplos níveis, do local para o global. A ênfase agora está em uma literatura de indicadores para serem aplicados em realidades locais. Com todas as críticas que se possa fazer a esses 
indicadores, no sentido de que não consideram as especificidades políticas, jurídicas, econômicas e sociais locais, a atuação tem servido pelo menos para colocar a regulação da comunicação novamente em discussão, em locais onde esse debate tem sido silenciado, por exemplo, nos países latinoamericanos. Os temas do McBride e do artigo 19 da Declaração dos Direitos Humanos estão novamente em foco, mas em outro formato.

\section{Liberdade de expressão e direito à comunicação na metalinguagem regulatória}

Apesar das mudanças contextuais, o debate da NOMIC - o maior que já se travou no plano internacional sobre os fluxos de comunicação, com reflexos até os dias de hoje, daí sua importância - deixou como herança a polarização dos conceitos de liberdade de expressão e de direito à comunicação. Desde então, a liberdade de expressão está mais associada a um direito individual de se expressar entre os pares, a uma emanação da personalidade individual. Já o direito à comunicação é entendido como um direito difuso, coletivo, que remete à pluralidade e à diversidade dos meios de comunicação. Identifica-se com a cidadania e com a participação ativa do cidadão na sociedade.

Essa polarização está ligada não só ao auge da Guerra Fria, mas também à própria concepção de Estado e ao modelo jurídico adotado pelos países. $\mathrm{O}$ conceito de direito à comunicação identifica-se com uma concepção mais garantista de Estado, no sentido de exigir a intervenção estatal para garantir a efetivação desse direito. Tal concepção vem do Direito de origem europeia continental, ou romano-germânica (DAVID, 2002), tradição na qual bebe também o Direito latino-americano, devido à influência das antigas metrópoles.

O paradigma da modernização e a defesa da liberdade de expressão como um direito individual tem origem no Direito anglo-americano ou Common Law. Essa doutrina entende o interesse público como a soma dos interesses privados. Sob esse aspecto, a liberdade de expressão é vista como uma liberdade negativa, que prevê a ausência de coação externa, ou seja, compreende a intervenção do Estado como inimiga desse direito e, por isso, a limita. 
Owen Fiss (2005) chama essa concepção de teoria libertária. Tal teoria prega que a liberdade de expressão visa a proteger fundamentalmente a autonomia privada e o direito à expressão do pensamento isentas de interferências externas. Segundo ele, ela tem sido reforçada pelas decisões da Suprema Corte norte-americana dos últimos vinte anos. Os juízes têm interpretado a Primeira Emenda, na esfera regulatória, no sentido de "invalidar uma série de medidas legislativas e executivas destinadas a garantir maior igualdade na arena pública e a promover um debate livre e aberto" (FISS, 2005, p. 140). Essas decisões, segundo ele, acompanham a filosofia política da época, caracterizada por demandas de desregulação, retórica sobre orçamentos equilibrados, revoltas de contribuintes, o Novo Federalismo e privatizações.

Fora dos Estados Unidos, a onda privatista e neoliberal também assolou as jovens democracias latino-americanas. A regulação democrática da radiodifusão, que nunca se consolidou durante as ditaduras, tampouco ganhou espaço com o fim dos regimes militares. ${ }^{6}$ No Brasil, houve uma verdadeira batalha no capítulo da Comunicação Social, durante a Assembleia Constituinte de 1987-88, que opôs donos de veículos de comunicação e entidades da sociedade civil organizada participantes da luta pela democratização da comunicação. Motter (1994) chamou-a de "batalha invisível", porque foi silenciada pela mídia, apesar da polêmica: o relatório da Comunicação Social foi o único não aprovado nas comissões setoriais. O acordo só foi alcançado na Comissão de Sistematização. ${ }^{7} \mathrm{O}$ ponto de maior discórdia na Constituinte foi sobre o papel do Conselho de Comunicação Social como um órgão regulador nos moldes da FCC norte-americana. Dito conselho, ao final, tomou a forma de um órgão meramente consultivo do Poder Legislativo, criado há 23 anos, mas que funcionou por apenas quatro.

${ }^{6}$ Com exceção do Chile, que tem um sistema mais estruturado, e a partir de 2009, a Argentina.

${ }^{7}$ Para angariar votos para o grupo conservador, formado pelos parlamentares a favor das posições dos empresários, segundo Motter (1994), o Ministro das Comunicações, Antônio Carlos Magalhães, ele mesmo dono de empresas de mídia na Bahia, distribuiu concessões aos deputados e senadores, como moeda de troca. Motter comprova essa informação pelo número de concessões distribuído durante a Constituinte, muito superior às licenças distribuídas antes da Assembleia.

Revista de Direito, Estado e Telecomunicações, v. 4, n. 1, p. 137-172 (2012)

DOI: https://doi.org/10.26512/lstr.v4i1.21577 
A Constituição de 1988 prevê também a regulamentação do art. 221, que nunca foi ultimada.

Desde então, os empresários de comunicação, nas poucas vezes em que esse debate vem à tona, reforçam o sentido de liberdade de expressão como livre da intervenção estatal, livre iniciativa, livre de medidas regulatórias - a não ser quando, por exemplo, é de seu interesse a proteção do mercado contra a entrada das empresas de telecomunicação -; a "liberdade de empresa", para citar expressão de Venício Lima (2010). Diante de esforços regulatórios do Estado, os empresários de comunicação também invocam o fantasma da ditadura, do estado censor e, nas colunas e reportagens, usam o termo regulação como sinônimo de censura. A lei que rege a radiodifusão, por exemplo, é de 1962 e, em tempos de convergência tecnológica, está desatualizada. Nenhum dos anteprojetos de marco legal das comunicações já formulados pelo Executivo - o último, em 2010, foi coordenado pelo então ministro da Secretaria de Comunicação Social da Presidência da República, Franklin Martins - foi entregue ao Congresso. Os governos têm desistido do desgaste político com as empresas de comunicação.

Com esse argumento da liberdade de expressão compreendida no sentido da teoria libertária, os empresários conseguiram derrubar, no Supremo Tribunal Federal, a Lei de Imprensa, de 1967, que também foi acusada de ser uma norma autoritária. Mas em vez de derrubá-la parcialmente, ou seja, os artigos que carregavam esse autoritarismo, o STF invalidou também institutos como o direito de resposta, uma forma de responsabilizar a imprensa por aquilo que é publicado (LIMA, 2010). Esse exemplo analisado de forma mais detalhada por Venício Lima (2010) mostra que a compreensão da Corte Suprema brasileira sobre liberdade de expressão não é muito diferente da norte-americana.

Embora motivos históricos, políticos e econômicos expostos tenham ligado o conceito de liberdade de expressão à teoria libertária, o professor norte-americano Owen Fiss (2005) mostra que a não-intervenção do Estado não é suficiente para garantir a efetivação desse direito nem o da liberdade de imprensa. Essas liberdades ditadas pelos interesses do mercado privilegiam as mensagens de grandes conglomerados, especialmente da área de comunicação, elites políticas, intelectuais e artísticas, em detrimento dos que não têm acesso aos grandes veículos de comunicação. Na atualidade midiática (MARTINO, 2009), termo que se refere à intensa midiatização a 
partir do século XIX, a liberdade de expressão plena depende de acesso aos meios de comunicação. Se apenas alguns grupos têm esse acesso, escolhidos de acordo com a audiência e o lucro que geram, essa liberdade é cerceada pelo mercado.

A principal consequência do mercado no cerceamento da liberdade de expressão e de imprensa é o efeito silenciador da mídia. Determinados assuntos simplesmente não são discutidos, porque não convém aos interesses econômicos e políticos dos grandes grupos midiáticos. Um desses temas é justamente a regulação, capaz de mudar a atual configuração do mercado latino-americano, cuja característica é de assimetria do setor privado, segundo Mendel e Salomon (2011). Para Lima (2010) e Fiss (2005), esse silêncio distorce o processo de formação da razão pública, já que determinadas ideias não chegam ao conhecimento dos leitores e espectadores, ou pelo menos não chegam em igualdade de condições. Com o tema da regulação, isso é bem claro. Nas poucas vezes em que ela é discutida nos meios de comunicação, é tratada como sinônimo de censura. Por isso, no Brasil, pode-se dizer que a opinião pública é contra a regulação da comunicação, o que é perfeitamente compreensível na medida em que esse debate nunca foi feito de maneira livre e em igualdade de condições.

Para Fiss (2005), apenas quando a liberdade de expressão, direito fundamental nos Estados democráticos de Direito, for entendida sob o ponto de vista da teoria democrática, esse direito será efetivamente cumprido. Essa teoria identifica-se com a cidadania e a construção da vontade comum pela participação ativa do cidadão nos negócios da polis:

A preocupação com a autonomia individual é aqui centrada menos no emissor que nos receptores das mensagens. (...) A liberdade de expressão, sob tal ponto de vista, visa à construção de um ethos argumentativo-deliberativo, propiciando a realização do processo coletivo de debate e tomada de decisões na esfera pública. (FISS, 2005, p.6)

Para os articuladores dessa teoria, a liberdade de expressão seria, portanto, sinônimo de direito à comunicação, pois o propósito das garantias da liberdade de expressão e de imprensa é assegurar o debate público livre e 
aberto, que deve ser protegido e incentivado por meio de uma regulação estratégica do Estado. "A regulação, aqui, deixa de ser vista como um mal necessário para se erigir em verdadeira condição necessária da fruição das liberdades de expressão e de imprensa por todos os cidadãos." (FISS, 2005, p.7) Desse ponto de vista, a liberdade de expressão só será plenamente exercida se todos tiverem as mesmas condições de fazê-lo. Ela seria, portanto, uma liberdade positiva firmada quando o Estado cria condições equânimes para exercê-la. Afinal, o Estado contemporâneo não é mais o absolutista.

No caso da radiodifusão de sons e imagens, a necessidade de regulação é óbvia por razões técnicas: o espectro eletromagnético é um bem público limitado. Mas essas razões técnicas levam também a questões de cunho político e jurídico: se poucos terão licença para exibir sons e imagens e trata-se de um serviço público, é necessário regulá-lo para garantir pluralidade, acesso dos cidadãos, ampla representação social, ou seja, garantir a própria liberdade de expressão. Pois, como já foi dito, os donos dos veículos não podem ter mais direito de expressão do que outros grupos sociais, ainda mais em uma atividade que tem natureza de serviço público.

A liberdade de imprensa, nesse caso, não é ilimitada. Ela constitui-se como um dos pilares do Estado Democrático de Direito; é a liberdade de expressão assegurada à instituição imprensa. Mas esse direito pressupõe também responsabilidades e limites, como os crimes contra a honra, mensagens de cunho racista e nazista, programação violenta e de apelo sexual para crianças e adolescentes, pluralidade, cotas de programação regional e independente, combate ao monopólio, ao oligopólio e à propriedade cruzada. Desse modo, há uma sobreposição de dois direitos fundamentais:

São bem poucos direitos considerados fundamentais que não entram em concorrência com outros direitos também considerados fundamentais, e que, portanto, não imponham em certas situações e em relação a determinadas categorias de sujeitos uma opção. Não se pode afirmar um novo direito em favor de uma categoria de pessoas sem suprimir algum velho direito, do qual se beneficiavam outras categorias de pessoas. A dificuldade de escolha se revolve com a introdução dos limites à extensão de um dos dois direitos, de modo que seja em parte salvaguardado também o outro. (BOBBIO, 1992, p.21) 
No caso da regulação da comunicação, sobrepõem-se os direitos à liberdade de expressão e à liberdade de imprensa. Sob a égide da teoria democrática, a escolha recai sobre o primeiro, mais amplo do que o segundo. Isso não significa que a liberdade de imprensa não será preservada. Ela apenas não será ilimitada. Do mesmo modo que a liberdade de expressão é limitada quando posta ao lado do direito à privacidade:

No direito à liberdade de expressão, por um lado, e no direito de não ser enganado, excitado, escandalizado, injuriado, difamado, vilipendiado por outro. Nesses casos, que são a maioria, deve-se falar de direitos fundamentais não absolutos, mas relativos, no sentido de que a tutela deles encontra, em certo ponto, um limite insuperável na tutela de um direito igualmente fundamental, mas concorrente. (BOBBIO, 1992, p. 46)

Mesmo a liberdade de imprensa se vê limitada por esses direitos da dignidade da pessoa humana. Fica claro, portanto, que a liberdade de expressão e a liberdade de imprensa afetam tanto as pessoas individualmente como o desenvolvimento da sociedade e da vida social. E como garantir a efetivação desses direitos, sem que um ultrapasse os limites do outro?

Cabe, então, aos poderes públicos do Estado, como representantes democráticos dos cidadãos, propor medidas para garantir a efetividade desses direitos, elaborando um marco jurídico adequado para exigir 0 dever de informações verídicas, plurais, independentemente de que 0 serviço público de informação seja exercido por entes públicos ou privados. (MORAES, 2007, p.274)

Cabe ao Estado democrático garantir a efetivação desses direitos por meio da regulação do setor de comunicação e, mais especificamente, da radiodifusão, o serviço público de sons e imagens. A defesa da intervenção estatal coloca uma questão sobre quais os limites dessa atuação, para que ela não descambe para o totalitarismo. Não há uma resposta objetiva para essa questão na obra de Fiss (2005) e talvez nem mesmo na teoria da regulação. A resposta possível é combinar a dimensão defensiva contra ingerências indevidas da autoridade estatal com a dimensão protetiva, que demanda a intervenção do Estado para efetivar a participação, num processo constante de reflexão jurídica, política e institucional com o objetivo de construir 
parâmetros regulatórios democráticos. Essa é a chamada ironia da liberdade de expressão, título do livro de Fiss:

Nós devemos aprender a abraçar uma verdade que é cheia de ironia e contradição: que o Estado pode ser tanto um inimigo como um amigo do discurso; que ele pode fazer coisas terríveis para enfraquecer a democracia, mas também algumas coisas maravilhosas para fortalecê-la. Esta, eu receio, que é uma verdade complicada, muito mais complicada do que nos temos permitido admitir por um longo tempo, mas que ainda - eu espero - não está além do nosso alcance. (FISS, 2005, p.144)

Nesse ponto, são valiosos conceitos como o de controle social ${ }^{8}$ e de participação da sociedade civil na construção desses parâmetros, na construção do próprio Estado, dos modelos de regulação e de sociedade desejados.

Para os que não se convencem com a possibilidade de se encontrar esse equilíbrio sutil na intervenção estatal, ainda assim, seja pelo enfoque da atuação do Estado orientada pela teoria libertária, seja pela teoria democrática, nenhum desses paradigmas significa ausência de regulação. Tanto isso é verdade, que se verifica a existência de órgãos reguladores nos Estados Unidos e nos países europeus, porém com metalinguagens regulatórias diversas, ou seja, formas de atuar diferentes, que obviamente produzem resultados diferentes na configuração do setor. ${ }^{9}$ Nos Estados Unidos, por exemplo, a regulação de conteúdo feita pela Federal Communication Commision (FCC) é mais focada no controle de programas obscenos. Os europeus têm parâmetros mais rígidos. Na França, por exemplo, a autoridade reguladora chega a contar o número de inserções do governo e da oposição nos telejornais, para garantir o equilíbrio político. ${ }^{10}$

\footnotetext{
8"Por controle social se entende o conjunto de meios de intervenção, quer positivos quer negativos, acionados por cada sociedade ou grupo social a fim de induzir os próprios membros a se conformarem às normas que a caracterizam, de impedir e desestimular os comportamentos contrários às mencionadas normas, de restabelecer condições de conformação, também em relação a uma mudança do sistema normativo." (BOBBIO, 2000, p. 283)

${ }^{9}$ Para mais detalhes sobre as diferenças, ver Lins (2002).

${ }^{10}$ No Seminário Internacional de Comunicação Eletrônica e Convergência de Mídias, realizado em Brasília em novembro de 2010, representantes de órgãos reguladores da Argentina, Estados Unidos, França, Inglaterra, Portugal e Catalunha, na Espanha,
} 
Também a existência e a forma como funcionam os modelos regulatórios da comunicação no exterior são silenciados pela mídia, pelo menos no Brasil e em outros países latino-americanos. Assim mesmo, apesar do efeito silenciador, esse debate da regulação começa a vir à tona na América Latina, como fruto da ascensão dos governos de esquerda, mas, sobretudo, da superação de espectros da ditadura, da participação da sociedade civil e da consolidação dessas democracias recentes.

\section{A transição de paradigmas na regulação da comunicação audiovisual argentina}

A concentração de propriedade e a propriedade cruzada são marcas da mídia latino-americana. Por isso, quando a Argentina conseguiu aprovar não sem resistências - e agora tenta implementar uma lei que promete mudar a configuração do setor, tal processo foi visto com muita curiosidade pelo mundo e particularmente pelos vizinhos latino-americanos.

A Argentina herda a estrutura jurídica da família romano-germânica - ou da Europa Continental -, como colônia espanhola até 1816. As noções de liberdade de expressão e de liberdade de imprensa aparecem na legislação argentina antes mesmo da independência, no Decreto de 20 de abril de $1811^{11}$, por influência das revoluções liberais, principalmente a Francesa, com a Declaração dos Direitos do Homem e do Cidadão, e a NorteAmericana, cujos ideais reverberaram na América Latina.

As liberdades de expressão e de imprensa transpõem-se para a primeira Constituição, de $1819^{12}$, e mantêm-se no texto constitucional até os dias de hoje ${ }^{13}$, em três artigos:

expuseram, em linhas gerais, os modelos de regulação adotados por cada país. Disponível em www.convergenciademidias.gov.br, acesso em 27/10/11.

${ }^{11}$ Art. $1^{\circ}$ - Todos los cuerpos y personas particulares de cualquiera condición y estado que sean tienen libertad de escribir, de imprimir y publicar sus ideas políticas, sin necesidad de licencia, revisión y aprobación alguna anteriores a la publicación, bajo las restricciones y responsabilidades que se expresarán en el presente decreto. Art. $2^{\circ}$ - Por lo tanto quedan abolidos todos los actuales juzgados de imprenta y la censura de las obras políticas precedente a su impresión. Art. $3^{\circ}$ Los autores y impresores serán responsables respectivamente del abuso de esta libertad.

${ }^{12}$ Constituição de 1819, Capítulo II, art. 111 - La libertad de publicar sus ideas por la prensa es un derecho tan apreciable al hombre, como esencial para la Revista de Direito, Estado e Telecomunicações, v. 4, n. 1, p. 137-172 (2012) 
Art. 14 - Todos os habitantes da Nação gozam dos seguintes direitos conforme as leis que regulamentam seu exercício; a saber: (...) de publicar suas ideias pela imprensa sem censura prévia.

Art. 32 - 0 Congresso federal não ditará leis que restrinjam a liberdade de imprensa ou estabeleçam sobre ela jurisdição federal.

Art. 42 - Os consumidores e usuários de bens e serviços têm direito, na relação de consumo, à proteção de sua saúde, segurança e interesses econômicos; a uma informação adequada e veraz; à liberdade de escolha e a condições de trato equitativo e digno. As autoridades proverão a proteção a esses direitos, à educação para o consumo, à defesa da competência contra toda forma de distorção dos mercados, ao controle de monopólios naturais e legais, ao controle da qualidades e eficiência dos serviços públicos e à constituição de associações de consumidores e usuários. A legislação estabelecerá procedimentos eficazes para a prevenção e solução de conflitos e os marcos regulatórios dos serviços públicos de competência nacional, prevendo a necessária participação das associações de consumidores e usuários das províncias interessadas nos organismos de controle. (CONSTITUIÇÃO ARGENTINA)

Diferentemente do que ocorre com a Constituição brasileira, a Argentina não tem um capítulo exclusivo para a Comunicação Social, que é quase inteiramente dedicado à radiodifusão. A regulação do espectro eletromagnético é implementada via legislação infraconstituicional. De 1980 até 2009, a lei que regulava a radiodifusão era a Lei 22.285. Essa lei reconhece a radiodifusão como um serviço público, mas seus limites débeis de outorga de licenças - uma pessoa física ou jurídica poderia ter até 24 licenças para explorar os serviços de radiodifusão, uma para cada província argentina - provocaram a concentração do mercado de comunicação.

conservación de la libertad civil en un Estado; se observarán a este respecto reglas que el Congresso tiene aprobadas provisionalmente, hasta que la Legislatura las varie o modifique.

${ }^{13}$ A Constituição em vigor é de 1853, mas foi reformada em 1860, 1866, 1957 e 1994. 
Segundo Mastrini e Becerra (2010), o cenário do mercado de comunicações na Argentina apresenta três níveis de concentração midiática:

1) Concentração de mercado: os quatro primeiros operadores dos meios de comunicação mais massivos (televisão aberta, a cabo, imprensa escrita e rádio) dominam, em média, 78\% do mercado correspondente;

2) Presença de conglomerados: grupos de comunicação presentes em quase todos os setores (propriedade cruzada). Ex: Clarín e Telefónica;

3) Concentração de conteúdos: centralização geográfica da produção audiovisual em Buenos Aires, origem da maioria dos conteúdos reproduzidos no resto do país. Do total de horas exibidas nos canais de TV, 86\% são retransmissões de produções do Canal 11 (44\%) e do Canal $13(42 \%)$, com sede em Buenos Aires.

Além disso, a Lei 22.285 era um marco legal do período da ditadura, defasado tanto em aspectos políticos quanto tecnológicos. Sua substituição por um novo marco legal mais moderno e democrático era uma demanda da sociedade civil organizada estimulada pelo fato de que vários setores já haviam conseguido aprovar novas legislações em substituição às normas ditatoriais.

Desde 2009, a Argentina passa por um processo de transição de paradigmas que ainda se encontram em conflito. Percebe-se uma mudança na atuação do Estado no setor de comunicações, cujo divisor de águas é o ano de 2009, quando a Lei 22.285 foi substituída pela Lei de Serviços de Comunicação Audiovisual, número 26.522, promulgada em 10 de outubro. $\mathrm{O}$ novo marco legal assegura a pluralidade e o direito à comunicação aos cidadãos, bem como a criação de um órgão regulador que fiscaliza seu cumprimento, a Autoridade Federal de Serviços de Comunicação Audiovisual (AFSCA). Foram pouco mais de seis meses entre a apresentação do anteprojeto, no Teatro de La Plata, em 18 de março de 2009, e a aprovação nas duas casas do Congresso. O texto do anteprojeto foi baseado no documento 21 Pontos Básicos pelo Direito à Comunicação, uma plataforma comum de luta pela democratização da comunicação, formulada pela Coalizão por uma Radiodifusão Democrática e apresentada à sociedade argentina desde 2004. A Coalizão reúne acadêmicos, estudantes, profissionais e movimentos da sociedade civil organizada. 
O governo teve um papel preponderante na mudança da atuação do Estado no que diz respeito às políticas de comunicação na Argentina. A razão que fez com que as reivindicações da Coalizão entrassem na agenda governamental foi um embate entre a presidente Cristina Kirchner e o Clarín provocado por um conflito no campo. ${ }^{14}$ Até então, a relação entre o governo e o jornal ia bem. Cristina queria aumentar o imposto de exportação, mesmo com a oposição das quatro principais associações de empresários agropecuários argentinos. ${ }^{15}$ A ligação entre o grupo Clarín e esses empresários fez o jornal se opor à presidente e isso se viu refletido na construção cotidiana da imagem pública de Cristina (RAMÍREZ, 2010).

$\mathrm{O}$ anteprojeto foi submetido à consulta da população por meio de fóruns e audiências públicas em todo o país:

Governo, funcionários, legisladores, empresários, mas também organizações sociais e comunitárias, associações e sindicatos de jornalistas, povos originários, as universidades nacionais e inclusive gente sem vinculação direta com os meios de comunicação (além de ouvintes e telespectadores), entre outros atores e setores, contribuíram com a configuração de um debate que não tem antecedentes na história da radiodifusão na Argentina (...) Em quase 27 anos de continuidade do sistema democrático, é a primeira vez que se observa a participação direta na formação de uma lei nacional, não só em setores minoritários mas também de pessoas que se aproximaram dos fóruns sem nenhuma representatividade além do desejo de manifestar sua posição. (RAMÍREZ, 2010, p.2; 5-6)

Ao final dos fóruns e conferências, mais de 1.200 sugestões foram apresentadas ao anteprojeto. Algumas delas podem ser identificadas no texto final, que manteve a indicação da origem da proposta.

Portanto, o Executivo - por motivos específicos que envolvem o conflito circunstancial dos Kirchner com o grupo Clarín -, em relação à comunicação, passou de uma postura liberal para uma mais garantista. $\mathrm{O}$

\footnotetext{
${ }^{14}$ Há controvérsias sobre porque a presidente Cristina Kirchner apoiou o projeto de uma nova lei de meios. Alguns atores-chave do processo, especialmente os governistas, dizem que a ideia de um novo marco legal para a comunicação audiovisual é anterior ao conflito no campo. Mas é unânime a opinião de que se esse conflito não foi a causa de tudo, pelo menos acelerou bastante o processo.

${ }^{15}$ Sociedad Rural Argentina (SRA), Federación Agrária Argentina (FAA) y las Confederaciones Rurales Argentinas (CRA y Coninagro).
} 
Governo discutiu o anteprojeto de lei de serviços de comunicação audiovisual com a sociedade civil, recebeu ampla contribuição, e o enviou à Câmara dos Deputados em 27 de agosto de 2009. O Legislativo, de maioria kirchnerista, também aderiu à postura prol direito à comunicação. Os deputados fizeram apenas duas mudanças. A primeira foi aumentar de cinco para sete o número de diretores da Autoridad Federal de Servicios de Comunicación Audiovisual, o órgão regulador criado pela lei para fiscalizar seu cumprimento, e também da empresa Rádio e Televisão da Argentina S/E, a empresa pública de comunicação do país. A segunda mudança foi excluir as telefônicas do rol de empresas que podem produzir conteúdo audiovisual. ${ }^{16}$ A aprovação do texto na Câmara ocorreu em 17 de setembro e no Senado, em 10 de outubro, sem modificações.

Mas todo esse processo não se seu sem oposição:

as respostas dos empresários de meios foram coerentes com a defesa do status quo e de seus interesses, sustentando o dogma do mercado autorregulado e dos perigos da ingerência estatal. Junto com representantes políticos de direita, os empresários dos principais grupos de meios organizaram sua resistência à sanção de uma norma democrática para o setor a partir de dois princípios: em primeiro lugar, sustentar que a concentração em poucas mãos não prejudica a liberdade de expressão e, em segundo lugar, que o único poder que restringe a liberdade de expressão é o do Estado e o de sua gestão contingente ( 0 governo). ${ }^{17}$ [tradução nossa] (MARINO; MASTRINI; BECERRA, 2010, p. 2)

\footnotetext{
${ }^{16}$ Não é objetivo deste artigo analisar a lei do ponto de vista técnico. Nesse aspecto, pode-se dizer que ela nasceu velha, na medida em que não se refere à convergência tecnológica; proíbe a entrada das empresas de telecomunicação no setor, um movimento global que parece ser inevitável, entre outros aspectos. A análise em curso é feita do ponto de vista político-filosófico, da metalinguagem regulatória, do novo modelo adotado para orientar a regulação da comunicação audiovisual no país. 17 ...las respuestas de los empresarios de medios han sido coherentes com la defensa del status quo y sus intereses, sosteniendo el dogma del mercado autorregulado y de los peligros de la injerencia estatal. Junto con los representantes políticos de derecha, los empresarios de los principales grupos de medios organizaran su resistencia a la sanción de uma norma democrática para el sector a partir de dos princípios: em primer lugar, sostener que la concentración en pocas manos no perjudica la libertad de expresión y, en segundo lugar, que el único poder que restringe la libertad de expresión es el del Estado y el de su gestión contingente (el gobierno).
}

Revista de Direito, Estado e Telecomunicações, v. 4, n. 1, p. 137-172 (2012)

DOI: https://doi.org/10.26512/1str.v4i1.21577 
Como já era de se esperar, por sua conhecida posição sobre a regulação do setor, grupos privados de mídia, câmaras empresariais, a Sociedad Interamericana de Prensa (SIP), alguns jornalistas, principalmente os mais famosos, e políticos de correntes partidárias opostas ao governo acusaram a presidente de censura e até hoje afirmam que ela usa a lei e o órgão regulador criado para atingir os grandes grupos midiáticos, em especial o desafeto Clarín. Embora esses argumentos tenham o motivo principal de manter o status quo dos grupos midiáticos, a denúncia que eles fazem quanto à atuação governamental não pode ser desconsiderada, na medida em que toda a literatura de regulação da comunicação fala em um processo democrático, que permite ampla participação social, com independência não só dos grupos midiáticos, mas também do governo. Por isso é mais coerente afirmar que a Argentina ainda se encontra em um processo de transição de modelos regulatórios.

Tais atores que se opõem ao novo texto questionaram-no no Poder Judiciário assim que foi aprovado pelo Congresso, alegando falhas nos trâmites do projeto de lei no Congresso. A ação chegou à Suprema Corte argentina. Durante o julgamento, a lei permaneceu suspensa, entrando em vigor somente no dia 15 de junho de 2010, após decisão da Corte Suprema em favor da sua constitucionalidade.

O novo marco legal tem como fundamento o direito à comunicação, citado em vários artigos, principalmente no $2^{\circ}$ e no artigo 12 , inciso $\mathrm{X}$, que diz ser missão e função da AFSCA velar por esse direito. No artigo $2^{\circ}$, o papel do Estado na efetivação da liberdade de expressão é reconhecido: "o Estado deve salvaguardar o direito à informação, à participação, preservação e desenvolvimento do Estado de Direito, assim como os valores da liberdade de expressão" (ARGENTINA, 2009). Trata-se de uma nova concepção do papel do Estado na regulação da comunicação argentina, que vai ao encontro da concepção da teoria democrática segundo Owen Fiss (2005).

A Lei 26.522 está assentada em marcos jurídicos e políticos internacionais como a Convenção da UNESCO sobre a Proteção e a Promoção da Diversidade das Expressões Culturais, a Convenção de Genebra sobre a Sociedade da Informação, realizada em 2003, a declaração de Princípios sobre a Liberdade de Expressão da Organização dos Estados Americanos (OEA), a Diretiva EuropEia Televisão sem Fronteiras, dentre outros. Seus objetivos principais são regular os serviços de comunicação 
audiovisual, desenvolver mecanismos para a promoção, desconcentração e fomento da comunicação audiovisual, baratear, democratizar e universalizar as novas tecnologias de informação e comunicação:

A lei pretende regular não apenas os critérios de outorga de licenças de operação, mas também o monitoramento da qualidade do serviço e do atendimento a critérios de pluralismo, de ética, de divulgação de informações de interesse público, de respeito à Constituição e às leis, de proteção especial a crianças e jovens e de garantias à produção local. (LINS, 2009, p.14)

A metalinguagem da regulação da comunicação audiovisual, inclusive a a TV por assinatura, a partir da Lei 26.522, é orientada pelo conceito de direito à comunicação. Desse modo, pode-se dizer que a Argentina passa por um processo de transição de paradigmas. A atuação do Estado durante os 29 anos em que a Lei 22.285 esteve em vigor caracteriza-se por uma posição de não-regulação ou de regulação segundo os interesses do mercado. ${ }^{18}$ Trata-se de uma metalinguagem da regulação que se identifica com o paradigma da modernização, dos livres fluxos de informação e da compreensão da liberdade de expressão como a proteção da autonomia privada sem interferências externas. Essa metalinguagem pode ser comprovada pela configuração do mercado de comunicação, marcado pela concentração de propriedade e de produção de conteúdos, pela formação de grandes conglomerados e pela propriedade cruzada, sem que o Estado se posicionasse no sentido de evitar essa conformação. Outra prova dessa tonalidade regulatória encontra-se na relação amigável da mídia com os governos anteriores e inclusive com o governo Cristina Kirchner, até que a presidente tomasse uma medida que desagradasse os empresários argentinos como um todo - a elevação do imposto de exportação - e os donos de

\footnotetext{
${ }^{18}$ Diferentemente do Brasil, a Argentina tinha uma autarquia para regular a radiodifusão, o Conselho Federal de Radiodifusão (Confer). Porém, tratava-se de um órgão de arranjo institucional e atuação anti-democráticos, segundo acadêmicos e movimentos da sociedade civil organizada que pediam uma nova lei das comunicações para substituir o marco legal e as instituições da ditadura. Sem independência do Executivo, era controlado mediante um interventor. (MARINO; MASTRINI; BECERRA, 2010)
} 
empresas de comunicação em particular - com a aprovação de um novo marco legal para o setor.

Para se ter ideia dessa diferença na metalinguagem da regulação antes e depois da Lei 26.522, em termos práticos, algumas novidades do marco legal em vigor podem ser destacadas, particularmente no que diz respeito à concentração de propriedade. Se efetivamente cumpridos, os limites da nova lei podem produzir mudanças significativas na configuração do setor de comunicação audiovisual argentino, no sentido de promover a desconcentração e reduzir a assimetria do setor privado em relação ao público.

Em primeiro lugar, quando se tratar de prestadores de natureza privada, com ou sem fins lucrativos, os serviços de comunicação audiovisual são prestados mediante outorga do Estado, na forma de licença de serviço válida por dez anos e prorrogável por igual período. Vencido esse prazo, haverá nova licitação e o prestador que teve a licença vencida pode concorrer novamente em condições de igualdade com os demais pleiteantes. No caso de ente público, universidade, representação de povos originários ou da igreja católica, o Estado concede uma autorização. Todos os serviços licenciados ou autorizados podem veicular publicidade. É admitida também a permissão, a título precário, no caso de emissões experimentais ou destinadas a fins científicos.

Uma curiosidade, na Argentina, é que, mesmo depois da Lei 26.522, as outorgas de radiodifusão aberta que superem os $50 \mathrm{~km}$ de raio de cobertura e estejam em cidades com mais de quinhentos mil habitantes ficam a cargo do Poder Executivo. Somente as licenças em municípios com menos de quinhentos mil habitantes são de competência da autoridade reguladora, a Autoridade Federal de Serviços de Comunicação Audiovisual (AFSCA). Por que essa divisão foi mantida, sendo que organismos internacionais como a Unesco, em estudos de especialistas em regulação de radiodifusão, como Toby Mendel e Eve Salomon (2011) recomendam que a distribuição de outorgas seja tarefa do órgão regulador independente do governo, como forma de garantir a isenção e a pluralidade no processo de concessão? Por que tal opção, mesmo depois de consultar as legislações de diversos países do mundo para elaborar a Lei 26.522 e de realizar audiências públicas em diversas províncias, com ampla participação de movimentos da sociedade civil organizada e de acadêmicos? Esse é mais um motivo para afirmar que a 
Argentina encontra-se em um processo de transição, em que as novas estruturas, em fase de implementação, convivem com as velhas.

A participação de capital estrangeiro nos prestadores de natureza privada é limitada a $30 \%$.

Os limites no número de outorgas em nível nacional são: uma licença de serviço de radiodifusão por satélite; até dez licenças de serviço de comunicação audiovisual, aberta ou por assinatura, de rádio ou de TV, mais a titularidade de registro de um sinal de conteúdo; até 24 - número de províncias na Argentina - licenças por serviço de meio físico, em localidades distintas, com limites bem definidos de área de cobertura e de população alcançada; quem tiver licença de serviço de comunicação por meio físico não poderá deter registro de sinal de conteúdo.

Os limites em nível local são: uma licença de radiodifusão sonora AM; uma FM ou até duas se houver mais de oito emissoras na localidade; uma licença de TV aberta ou por assinatura mutuamente excludentes; em qualquer caso, máximo de três licenças; não será dada licença a quem já tenha outorga na área, ou em área adjacente com superposição, quando se tratar da única frequência ainda disponível.

Em nenhum caso, o total de licenças detidas pode superar os $35 \%$ da população ou do total de assinantes do serviço. A lei também estabelece restrições à formação de redes e fixa o prazo de um ano para que as empresas se adéquem aos novos limites de propriedade, o que também está sendo questionado no Poder Judiciário, órgão em que a disputa de paradigmas em torno do modelo de regulação da comunicação continua saliente. $\mathrm{O}$ argumento das empresas é de que a lei não pode retroagir, ou seja, as novas regras só devem valer para as novas licenças. A previsão é de que o julgamento seja realizado até 2013.

Durante a transição da televisão analógica para a digital, será admitida a convivência de licenças até a substituição da tecnologia. Atualmente, a autoridade reguladora está fazendo licitações para a concessão dos canais digitais, que não serão dados automaticamente aos atuais licenciados analógicos, como foi feito no Brasil.

A lei fixa, ainda, quotas de programação nacional e local. Emissoras de rádio não estatais devem emitir pelo menos $70 \%$ de programação nacional; $30 \%$ da música deve ser nacional e metade (15\%) de produção independente. Pelo menos metade da programação deve ser jornalística. Revista de Direito, Estado e Telecomunicações, v. 4, n. 1, p. 137-172 (2012) 
Emissoras temáticas ou destinadas a comunidades estrangeiras podem ser liberadas dessa obrigação. No caso da TV aberta, no mínimo $60 \%$ da grade deve ser de programação nacional e $30 \%$ de produção própria. A quota de programação local independente é de $30 \%$ para estações em localidades com mais de 1,5 milhão de habitantes, $15 \%$ para localidades com mais de 600 mil habitantes e $10 \%$ para localidades abaixo de 600 mil habitantes. A quota de tela para a TV aberta é de oito longas argentinos por ano. Há também obrigações para a TV por assinatura e para as emissoras estatais e de universidades públicas. Por fim, cabe destacar a existência da classificação indicativa, da exigência de que $50 \%$ dos programas destinados à infância sejam de produção argentina e do acesso universal a eventos esportivos de interesse nacional, como os jogos de futebol.

As diferenças entre o antigo marco legal e o atual foram esquematicamente inseridas na tabela a seguir:

\begin{tabular}{|c|c|}
\hline Antiga lei (Lei 22.285/80) & Nova lei (Lei 26.522/2009) \\
\hline $\begin{array}{l}\text { - limite de } 24 \text { licenças de rádio e TV } \\
\text { - não havia limites para a TV por } \\
\text { assinatura } \\
\text { - permitia a propriedade simultânea de } \\
\text { programadores e de transmissores de } \\
\text { TV aberta e por assinatura } \\
\text { - impedia sociedade sem fins lucrativos } \\
\text { de ser detentora de concessão } \\
\text { (permissão para tanto surgiu em 2005) }\end{array}$ & $\begin{array}{l}\text { - limite de } 10 \text { licenças (artigo 161) e } \\
\text { até } 35 \% \text { do mercado potencial } \\
\text { - limite da propriedade cruzada de } \\
\text { meios eletrônicos (mas não } \\
\text { eletrônicos e impressos) } \\
\text { - proíbe ser proprietário de } \\
\text { distribuidoras de cabo e canal de TV } \\
\text { aberta na mesma região } \\
\text { - distribuidoras de cabo só podem ter } \\
\text { uma concessão própria } \\
\text { - reserva 33\% do espectro para } \\
\text { organizações sem fins lucrativos } \\
\text { - proíbe as telefônicas de deter } \\
\text { licenças de meios } \\
\text { - cota de } 30 \% \text { de produção própria }\end{array}$ \\
\hline
\end{tabular}


Reeleita e empossada no dia 10 de dezembro de 2011, Cristina Kirshner prometeu, na cerimônia de posse, dar prioridade ao cumprimento da Lei de Serviços de Comunicação Audiovisual no segundo mandato. Mas o governo, que teve um papel preponderante na transição de paradigmas, também coloca entraves para se consolidar o modelo democrático do direito à comunicação na regulação argentina. As críticas dos entes regulados parecem não ser infundadas, na medida em que os próprios defensores da regulação da comunicação audiovisual e ao novo marco legal reconhecem os obstáculos que o governo impõe para a efetivação da nova legislação:

Há três forças que impõem obstáculos à plena instrumentação da norma: o próprio governo, a oposição e os grupos privados concentrados. 0 governo porque está obcecado com alguns artigos da lei que estão inspirados na disputa com 0 grupo Clarín ${ }^{19}$ [tradução nossa]. (BECERRA, 2011)

Portanto, a efetivação do direito à comunicação, da regulação democrática e da postura do Estado como garantidor de direitos depende do equilíbrio sutil na intervenção estatal, cujo excesso pode dar razão às críticas da ameaça de um Estado totalitário. Por outro lado, a omissão do Estado, situação que se verificava antes de 2009 na Argentina, representa a exclusão do discurso público de grupos sociais econômica e politicamente desfavorecidos e a manipulação desse discurso por grupos hegemônicos controladores da comunicação. O cenário regulador argentino sobre a comunicação audiovisual ainda depende da participação intensa da sociedade civil e da consolidação das políticas públicas de regulação da comunicação, de modo que os entes regulados participem da construção dessas políticas. É um processo complexo e demorado, vinculado ao amadurecimento político, mas cuja efetividade pode ser vista nas experiências regulatórias em democracias como as europeias e até mesmo a norte-americana, que a seu modo, dentro do paradigma da modernização e da Common Law, construiu seu modelo regulatório, menos garantista, é fato, mas longe da ausência de regulação.

${ }^{19}$...hay tres fuerzas que obstacularizan la plena instrumentación de la norma: el propio Gobierno, la oposición y los grupos privados concentrados. El Gobierno porque está obsesionado con algunos artículos de la ley que están inspirados em la disputa con el grupo Clarín.

Revista de Direito, Estado e Telecomunicações, v. 4, n. 1, p. 137-172 (2012)

DOI: https://doi.org/10.26512/lstr.v4i1.21577 


\section{Bibliografia}

ARGENTINA. Constitución Nacional. Disponível em http://www.senado.gov.ar/web/interes/constitucion/cuerpo1.php, acesso em 31/10/2011.

ARGENTINA. Ley 22.285, 15 de setembro de 1980. Buenos Aires: 1981. Disponível em http://www.comfer.gov.ar/leyderadiodifusion22285.php , acesso em 31/10/2011.

ARGENTINA. Ley 25.188, 26 de outubro de 1999. Disponível em http://www.infoleg.gov.ar/infolegInternet/anexos/6000064999/60847/texact.htm, acesso em 31/10/2011.

ARGENTINA. Ley 26.522, de 10 de outubro de 2009. Buenos Aires: 2009. Disponível em http://www.comfer.gov.ar/web/ley26522.pdf, acesso em 30/08/2010.

AUTORIDAD FEDERAL DE SERVICIOS DE COMUNICACIÓN AUDIOVISUAL. Página na internet: www.afsca.gov.ar, acesso em 31/10/2011.

BARANCHUK, Mariana; USÉ, Javier R. (orgs.). Ley 26.522: hacia un nuevo paradigma en comunicación audiovisual. $1^{\text {a }}$ ed. Lomas de Zamora: Facultad de Ciencias Sociales, Universidad de Lomas de Zamorra, 2011.

BECERRA, Martín. LCSA 2 años - Evaluación y propuestas. 2011 (mimeo)

BECERRA, Martín. Medios de comunicación oficiales: transgresión y propaganda. In: Revista El Estadista ${ }^{\circ} 30$ (28/4 al 11/5/2011).

BOBBIO, Norberto. A era dos direitos. Rio de Janeiro: Campus, 1992.

BOBBIO, Norberto. Dicionário de política. $5^{\mathrm{a}}$ ed. Brasília: Editora Universidade de Brasília: São Paulo: Imprensa Oficial do Estado de São Paulo, 2000.

CARLSSON, Ulla. The rise and fall of Nwico - From a vision of international regulation to a reality of multilevel governance. Gotemburg: Nordicom, 2003.

COALICIÓN POR UMA RADIODIFUSIÓN DEMOCRÁTICA. 21 Puntos Básicos por el Derecho a la Comunicación. Disponível em www.coalicion.org.ar, acesso em 21/10/2011. 
CONSTANT, Benjamin. Da liberdade dos antigos comparada à dos modernos. In: Filosofia política. $\mathrm{n}^{\circ} 2$, São Paulo; Porto Alegre: L\&PM Editores, 1985, p. 9-25.

CONSTITUCIÓN DE LA NACIÓN ARGENTINA, concordata con sus reformas y antecedentes. Buenos Aires: Editorial Ástrea de Rodolfo Depalma y Hnos, 1973.

DAVID, René. Os grandes sistemas do direito contemporâneo. São Paulo: Martins Fontes, 2002.

FISS, Owen M. A ironia da liberdade de expressão: Estado, regulação e diversidade na esfera pública. Rio de Janeiro: Renovar, 2005.

INTERVOZES. Contribuições para a construção de indicadores do direito à comunicação. São Paulo: Intervozes, 2010.

LIMA, Venício A. Liberdade de expressão $x$ liberdade de imprensa: direito à comunicação e democracia. São Paulo: Publisher Brasil, 2010.

LINS, Bernardo. Análise comparativa de políticas públicas de comunicação social. (Nota técnica) Brasília: Consultoria Legislativa da Câmara dos Deputados, 2002. Disponível em http://www.belins.eng.br/tr01/reports/109752.pdf, acesso em 23/4/2010.

LINS, Bernardo. Argentina: nova lei dos meios audiovisuais. (Nota técnica) Brasília: 2009. Disponível em http://belins.eng.br/tr01/reports/2009 17122.pdf, acesso em 17/6/2011.

MAIA, Kenia. PEREIRA, Fábio H. Liberdade de imprensa e identidade profissional no jornalismo: mito fundador ou discurso de autolegitimação. In: MOURA, D. [et al.] (orgs.) Comunicação e cidadania: conceitos e processos. Brasília: Francis, 2011.

MARINO, S. MASTRINI, G. BECERRA, M. Argentina: regulación democrática y desafios de su aplicación. 2010 (mimeo)

MARTINO, L. C. A atualidade mediática: o conceito e suas dimensões. XVIII Encontro da Compôs, PUC-Minas, junho de 2009.

MASTRINI, G. BECERRA, M. Globalización, mercado e industrias culturales: resistencia o simulacro? In: Diálogos pela Comunicación, Revista Académica de la Federación Latinoamericana de Facultades de Comunicación Social (Felafacs). Disponível em: www.dialogosfelafcs.net/75/articulos/pdf/75MastriniBecerra.pdf, acesso em $6 / 5 / 2011$. 
MASTRINI, G. BECERRA, M. Periodistas y magnates: estrutura y concentración de las industrias culturales en América Latina. Buenos Aires: Prometeo e IPyS Ediciones, 2006.

MAZZIOTTI, Nora. La televisión en Argentina. In: OROZCO, G. (org) Historias de la televisión en América Latina. Barcelona: Editorial Gedisa, 2002.

MENDEL, Toby. SALOMON, Eve. O ambiente regulatório para a radiodifusão: uma pesquisa de melhores práticas para os atores-chave brasileiros. Brasília: Unesco, 2011.

MILTON, John. Areopagítica. Buenos Aires: Fondo de Cultura Económica, 1976.

MORAES, Geórgia. A tensão entre liberdade de expressão e direito à informação - empecilho à elaboração de políticas públicas de comunicação. In: RAMOS, Murilo. SANTOS, Suzy dos. (orgs.) Políticas de Comunicação - buscas teóricas e práticas. São Paulo: Paulus, 2007.

MOTTER, Paulino. A batalha invisivel da Constituinte - Interesses privados versus caráter público da radiodifusão no Brasil. Brasília: dissertação de Mestrado, UnB/Faculdade de Estudos Sociais Aplicados, 1994.

OlIVEIRA, Marcio N. I. A. Políticas Públicas comparadas de telecomunicações (Brasil - EUA). Tese de doutorado defendida no Centro de Pesquisa e Pós-Graduação sobre as Américas. Brasília: Universidade de Brasília, 2005.

RAMIREZ, Alejandro M. Sectores, actores e intereses en torno a la ley de servicios de comunicación audiovisual en la Argentina (2009-2010). Bogotá: X Congresso Alaic, 2010.

RIBEIRO, Bráulio C. O modelo de desconcentração do mercado audiovisual da Argentina proposto pela nova Lei de Meios. Brasília, 2010 (mimeo).

SARAVIA, Enrique. MARTINS, Paulo E. M. PIERANTI, Octavio Penna. (orgs.). Democracia e regulação dos meios de comunicação de massa. Rio de Janeiro: Editora FGV, 2008.

SECRETARIA DE COMUNICAÇÃO SOCIAL DA PRESIDÊNCIA DA REPÚBLICA. Seminário Internacional de Comunicação Eletrônica e Convergência de Mídias. Brasília, novembro, 2010. Disponível em www.convergenciademidias.gov.br, acesso em 27/10/11. 
UNESCO. Um Mundo e Muitas Vozes - Comunicação e informação na nossa época. Rio de Janeiro: Editora da Fundação Getúlio Vargas, 1983. 